\title{
Diyabet Hastalarında Serum Magnezyum Düzeyi ile Glisemik Regülasyon ve Proteinüri Arasındaki İlişki
}

\section{The Relationship Between Serum Magnesium Level and Glycemic Regulation and Proteinuria in Diabetic Patients}

\author{
Mehmet Ali Mısırlığlu ${ }^{1}$, Hüseyin Erdal2*, Oğuzhan Özcan ${ }^{3}$, Faruk Turgut ${ }^{4}$ \\ ${ }^{1}$ Hatay Mustafa Kemal Üniversitesi, Tayfur Ata Sökmen Tıp Fakültesi, İç Hastalıkları A.D., Hatay, Türkiye \\ ${ }^{2}$ Hatay Mustafa Kemal Üniversitesi, Tayfur Ata Sökmen Tıp Fakültesi, Moleküler Biyokimya ve Genetik A.D., \\ Hatay, Türkiye \\ ${ }^{3}$ Hatay Mustafa Kemal Üniversitesi, Tayfur Ata Sökmen Tıp Fakültesi, Tıbbi Biyokimya A.D, Hatay, Türkiye \\ ${ }^{4}$ Hatay Mustafa Kemal Üniversitesi, Tayfur Ata Sökmen Tıp Fakültesi, İç Hastalıkları A.D., Nefroloji B.D., Hatay, \\ Türkiye
}

E-mail:malimsr@hotmail.com, herdalyfa@gmail.com,drozan29@hotmail.com, turgutfaruk@yahoo.com ORCID: 0000-0002-4171-9148

ORCID: 0000-0003-0786-5077

ORCID: 0000-0001-7486-503X

ORCID: 0000-0003-1910-7433

*Sorumlu Yazar / Corresponding Author: Sorumlu Yazar: Hüseyin Erdal ${ }^{2}$

Gönderim Tarihi / Received: 18.10.2019

Kabul Tarihi / Accepted: 07.04.2019

DOI: $10.34087 /$ cbusbed.634532

Giriş ve Amaç: Magnezyum vücutta birçok önemli fonksiyonu olan eser elementlerden biridir. Magnezyum eksikliğinde en sık karşılaşılan klinik problemlerden birisi insülin direncidir. Diyabet son dönem böbrek hastalığının en sık nedenidir. Magnezyum eksikliği diyabetik hastalarda sık görülmektedir ve diyabet komplikasyonları ile ilişkili olduğu gösterilmiştir. Bu çalışmada diyabetik hastalarda serum magnezyum düzeyi ile glisemik regülasyon ve proteinüri arasında ilişki olup olmadığının araştırılması amaçlanmıştır.

Gereç ve Yöntemler: Bu kesitsel çalışmaya 189 Tip 2 diabetes mellitus (DM) hastası alındı. Hastaların demografik ve klinik özellikleri ile kan basınçları kaydedildi. Hastalardan alınan serum örneklerinden glukoz, Hemoglobin A1c (HbA1c), BUN, kreatinin, elektrolitler, lipit profili, magnezyum, kalsiyum düzeyleri ve tam kan sayımı çalış1ldı. 24 saatlik idrarda proteinüri bakıldı.

Bulgular: Hipomagnezemi (<1,7 mg/dl) 64 hastada (\% 34) saptand1. Hipomagnezemi grubunda ortalama glukoz ve HbA1c düzeyleri anlamlı bir şekilde daha yüksek saptandı. Aynı şekilde hipomagnezemi grubunda ortalama proteinüri miktarı belirgin olarak daha yüksek bulundu. Serum magnezyum düzeyi ile HbA1c, glukoz ve proteinüri değerleri arasında zayıf da olsa negatif bir korelasyon saptand1 (sirasiyla $\mathrm{r}=-0.187, \mathrm{p}=0.011, \mathrm{r}=-0.152, \mathrm{p}=0.039, \mathrm{r}=-0.149$, $\mathrm{p}=0.044$ ). Serum magnezyum düzeyi ile yaş, beden kitle indeksi, eGFR, diyastolik ve sistolik kan basıncı arasında anlamlı bir ilişki saptanmadı.

Sonuç: Hipomagnezemi Tip 2 DM hastalarında sık görülmektedir. Glisemi regülasyonu bozuk olan diyabetik hastalarda serum magnezyum düzeyinin kontrol edilmesi önemlidir. Bu hasta grubunda serum magnezyum düzeyi ile glisemi regülasyonu ve proteinüri arasında zayıf da olsa anlamlı bir ilişki olabilir.

Anahtar Sözcük: Proteinüri, diyabet, magnezyum, glisemik regülasyon

Abstract

Objective: Magnesium is one of the trace elements with many functions in the body. One of the most common clinical problems in magnesium deficiency is insulin resistance. Diabetes is the most common cause of end-stage renal disease. Magnesium deficiency is common in diabetic patients and has been shown to be associated with diabetes complications. The aim of this study was to investigate the relationship between serum magnesium level and glycemic regulation and proteinuria in diabetic patients. 
Materials and Methods: This type of cross-sectional study included 189 patients with Type 2 diabetes mellitus (DM). Demographic and clinical characteristics and blood pressures were recorded. Glucose, Hemoglobin A1c (HbA1c), BUN, creatinine, electrolytes, lipid profile, magnesium, calcium levels and complete blood count were studied from serum samples. Proteinuria was measured in 24-hour urine.

Results: Hypomagnesemia ( $<1,7 \mathrm{mg} / \mathrm{dl})$ was detected in 64 patients $(34 \%)$. The mean glucose and HbA1c levels were significantly higher in the hypomagnesemia group. Similarly, the mean amount of proteinuria was significanlty higher in the hypomagnesemia group. There was a weak negative correlation between serum magnesium level and $\mathrm{HbA1c}$, glucose, and proteinuria values were detected (respectively, $\mathrm{r}=-0.187, \mathrm{p}=0.011, \mathrm{r}=-0.152, \mathrm{p}=0.039, \mathrm{r}=-$ $0.149, \mathrm{p}=0.044)$. There was no significant relationship between serum magnesium level and age, body mass index, eGFR, diastolic and systolic blood pressure.

Conclusion: Hypomagnesemia is common in Type 2 DM patients. It is important to control serum magnesium levels in diabetic patients with impaired glycemic regulation. In this patient group, there may be a weak significant correlation between serum magnesium level and glycemic regulation and proteinuria.

Keywords: Proteinuria, diabetes, magnesium, glycemic regulation

\begin{abstract}
1. Giriş
Diyabet dünya genelinde ve özellikle gelişmekte olan ülkelerde de sıklığı hızla artan ve acil olarak ele alınması gereken bir halk sağlığı sorunudur [1]. Uluslararası Diyabet Federasyonun tahminine göre tüm dünya genelinde 245 milyondan fazla kişinin diyabet hastalığına sahip olduğu ve önümüzdeki 20 yıl içinde bu sayının 380 milyon kişiye ulaşacağı tahmin edilmektedir [2]. Diyabetin mikrovasküler ve makrovasküler komplikasyonları önemli bir morbidite ve mortalite nedeni olarak karşımıza çıkmaktadır. Ülkemizde diyabet son dönem böbrek hastalığının en sık nedenidir. Diyabete bağlı böbrek hastalığının en erken bulgusu idrarla albümin atılımının artmasıdır.
\end{abstract}

Vücudumuzdaki birçok metabolik olayın gerçekleşmesinde ve organizmanın sağlıklı bir yaşam sürdürmesinde eser elementler son derece önemli olup bu eser elementlerden birisi de magnezyumdur. Magnezyum, glukoz metabolizması ile ilişkili enzimler için önemli bir kofaktördür ve insülin duyarlılığının artırılması ve Tip 2 diyabetin önlenmesinde önemli bir potansiyele sahiptir [3]. Magnezyumun pankreatik beta hücre döngüsünün korunması, insülin salınımı, insülin etkisinin düzenlenmesi, insülin aracılı glukoz alımının düzenlenmesi, glukoz metabolize edici enzimlerin aktivasyonu, vasküler tonusun korunması ve DNA sentezi gibi çeşitli biyokimyasal olaylarda önemli rol oynadığı gösterilmiştir [4-6]. Bundan dolayı magnezyum glukoz metabolizmasında, insülin dengesinde ve diyabetin gelişmesinde çok önemli bir role sahiptir. $\mathrm{Bu}$ çalışmada, Tip 2 Diyabetes Mellitus (DM) hastalarında serum magnezyum düzeyi ile glisemik regülasyon ve proteinüri arasında ilişki olup olmadığının araştırılması amaçlanmıştır.

\section{Materyal ve Metot}

$\mathrm{Bu}$ kesitsel çalışmaya Mustafa Kemal Üniversitesi İç Hastalıkları polikliniklerine başvuran 189 Tip 2 Diyabetes Mellitus hastası dahil edildi. Çalışmada Helsinki Deklarasyonu prensiplerine uyulmuş olup, hastanemizin kurumsal inceleme kurulu ve etik kurul komitelerinden gerekli izinler alındı. Hastaların demografik ve klinik özellikleri, hasta özgeçmişleri (alkol ve sigara kullanımı, eşlik eden kronik hastalıklar) ve kan basınçları kaydedildi. Kronik karaciğer hastalığı, kalp yetmezliği, akciğer yetmezliği, aktif malignitesi olanlar, gebeler, 18 yaş altı kişiler ve madde bağımlılığ 1 olanlar çalışma dişı birakılmıştır.

Hastalardan bir gecelik açlık sonrası (8 saatlik) alınan kan örnekleri 3000 devirde 4 dakika santrifüj edildikten sonra serumları $-80^{\circ}$ sakland1. Glukoz, Hemoglobin A1c (HbA1c), BUN, kreatinin, elektrolitler, lipit profili, magnezyum ve kalsiyum düzeyleri ile tam kan sayımı oto analizörde çalışıldı. Spot idrarda protein ve kreatinin düzeylerine bakıldı. Protein/kreatinin oranı hesaplanarak hastaların proteinüri düzeyleri belirlendi. Hastaların tahmini glomerüler filtrasyon değerleri (eGFR), kreatinin düzeyleri kullanarak CKD-EPI formülü ile hesaplandı.

\section{Istatistiksel Analiz}

Çalıșma verilerinin istatistiksel analizi için SPSS (Statistical Package for Social Science, Worldwide Heaquarters SPSS Inc.) 21.0 Windows paket programı kullanıldı. Çalışma sonuçları ortalama ve standart sapma $(\mathrm{X} \pm \mathrm{SD})$ olarak verildi. Verilerin normal dağılıma uyup uymadığı Kolmogorov-Smirnov testi yapılarak belirlendi. Normal dağılıma uyan verilere parametrik bir test olan Student $\mathrm{T}$ testi uyguland1 ve $\mathrm{p}<0.05$ anlamlı olarak kabul edildi. Normal dağılıma uyan veriler arasında Pearson korelasyon analizi yapıldı.

\section{Bulgular}

Çalışmaya dahil edilen hastaların ortalama yaşı $55 \pm 8$ idi. Hipomagnezemi (<1.7 mg/dl) 64 hastada (\% 34) saptandı. Çalışmaya alınan hastalar serum magnezyum düzeyine göre iki gruba ayrıldı. Serum magnezyum düzeyi normal sınırın altında (Magnezyum <1.7 mg/dl) olan hastalar hipomagnezemi grubu $(n=64)$ ve serum magnezyum düzeyi $1.7 \mathrm{mg} / \mathrm{dl}$ 'nin üzerinde olan hastalar normomagnezemi grubu $(\mathrm{n}=125)$ olarak kabul edildi. Tablo 1'de her iki gruptaki hastaların demografik verileri ve ortalama kan basıncı sonuçları verilmiştir.

Yaş, cinsiyet, beden kitle indeksi ve kan basınçları açısından iki grup arasında anlamlı bir fark saptanmadı. Tablo 2'de hastaların laboratuvar değerleri verilmiştir. Hipomagnezemi grubunda ortalama glukoz ve HbA1c düzeyleri anlamlı bir şekilde daha yüksek saptandı. Aynı şekilde hipomagnezemi grubunda ortalama proteinüri miktarı belirgin olarak daha yüksek bulundu. 
Tablo 1. Hastaların demografik verileri

\begin{tabular}{|c|c|c|c|}
\hline Hastaların karakteristiği & $\begin{array}{l}\text { Hipomagnezemi } \\
(n=64)\end{array}$ & $\begin{array}{l}\text { Normomagnezemi } \\
\qquad(\mathrm{n}=125)\end{array}$ & $\mathrm{p}$ \\
\hline Cinsiyet (erkek / kadın) & $35 / 29$ & $70 / 55$ & 0.864 \\
\hline Yaş (yıl) & $55 \pm 8$ & $54 \pm 8$ & 0.701 \\
\hline VKİ (kg/m²) & $31 \pm 5.6$ & $30 \pm 5$ & 0.103 \\
\hline Sistolik KB (mmHg) & $136 \pm 15$ & $133 \pm 16$ & 0.218 \\
\hline Diyastolik KB (mmHg) & $79.6 \pm 10$ & $79.7 \pm 10$ & 0.965 \\
\hline
\end{tabular}

VKİ: Vücut Kitle İndeksi, KB: Kan Basıncı

Tablo 2. Hastaların laboratuvar değerleri

\begin{tabular}{|c|c|c|c|}
\hline Laboratuvar değerleri & $\begin{array}{l}\text { Hipomagnezemi } \\
\qquad(n=64)\end{array}$ & $\begin{array}{l}\text { Normomagnezemi } \\
\qquad(\mathrm{n}=125)\end{array}$ & $\mathrm{p}$ \\
\hline Glikoz (mg/dl) & $204.6 \pm 77$ & $171.9 \pm 77$ & 0.007 \\
\hline $\operatorname{HbA1c}(\%)$ & $10 \pm 2.5$ & $9 \pm 2.4$ & 0.006 \\
\hline Sodyum (mmol/L) & $137 \pm 2.8$ & $137 \pm 2.6$ & 0.039 \\
\hline Potasyum (mmol/L) & $4.7 \pm 0.52$ & $4.5 \pm 0.46$ & 0.069 \\
\hline Kalsiyum (mg/dl) & $9.24 \pm 0.84$ & $9.20 \pm 0.47$ & 0.712 \\
\hline Fosfor (mg/dl) & $3.65 \pm 0.86$ & $3.54 \pm 0.72$ & 0.334 \\
\hline Magnezyum (mg/dl) & $1.59 \pm 0.11$ & $1.92 \pm 0.22$ & 0.000 \\
\hline LDL-Kolesterol (mg/dl) & $132.6 \pm 50.9$ & $132.3 \pm 41.86$ & 0.986 \\
\hline HDL-Kolesterol (mg/dl) & $38 \pm 10$ & $38.5 \pm 10.6$ & 0.788 \\
\hline Trigliserit (mg/dl) & $213.5 \pm 162.3$ & $186 \pm 99$ & 0.220 \\
\hline Total Kolesterol (mg/dl) & $209.8 \pm 59.8$ & $207 \pm 44$ & 0.758 \\
\hline GFH (ml/dk/1.73 m²) & $91.8 \pm 16.8$ & $96.3 \pm 15.4$ & 0.068 \\
\hline $\begin{array}{l}\text { Proteinüri } \\
(\text { çeyreklik }))\end{array} \quad$ (mg/gün) $\quad$ (medyan & $160(45-404)$ & $117(60-184)$ & 0.049 \\
\hline
\end{tabular}

GFH: Glomerüler Filtrasyon Hızı, HbA1c: Hemoglobin A1c

Serum magnezyum düzeyi ile $\mathrm{HbA1c}$, glukoz ve proteinüri değerleri arasında zayıf da olsa negatif bir korelasyon saptand 1 (sirasiyla $\mathrm{r}=-0.187, \mathrm{p}=0.011, \mathrm{r}=$ $0.152, \mathrm{p}=0.039, \mathrm{r}=-0.149, \mathrm{p}=0.044)$. Serum magnezyum düzeyi ile yaş, beden kitle indeksi, eGFR, diyastolik ve sistolik kan basıncı arasında anlamlı bir ilişki saptanmadi.

\section{Tartışma}

Bu çalışmada Tip 2 DM hastalarında hipomagnezemi sıklığ1 \%34 olarak saptand. Hipomagnezemisi olan DM hastalarında serum glikoz ve HbA1c düzeyleri belirgin olarak yüksek bulundu. Serum magnezyum düzeyleri ile HbAlc, glukoz ve proteinüri değerleri arasında zayıf da olsa negatif bir korelasyon saptand 1 .

Diyabetik hastalarda magnezyum eksikliği veya hipomagnezemi sık görülen bir durumdur ve Tip 2 DM hastalarında toplam magnezyum düzeyi normal olsa bile iyonize magnezyumun genellikle düşük olduğu bilinmektedir [7, 8]. Magnezyum, hücre içerisinde fazla miktarda bulunan bir mineral olup metabolik ve enzimatik reaksiyonlar için önemli bir kofaktördür $[9$, 
10]. İnsan vücudundaki magnezyumun yaklaşık \%99'u intraselüler (\% 50-55'i kemik dokusu, geri kalanı kas ve diğer yumuşak dokularda) ve \% 1'nin ekstraselüler (plazma ve eritrositlerde) alanda olduğu bilinmektedir [9]. Ancak klinik laboratuvarlarda çoğunlukla serum total magnezyum düzeyi belirlenebilmektedir ve magnezyum durumunun klinik laboratuvar değerlendirmesi öncelikle total serum magnezyum konsantrasyonu ve 24 saatlik idrar atılımı ile sinırlıdır [10]. Magnezyum, hem uygun glikoz kullanımı hem de insülin sinyalizasyonu için gereklidir ve insülin direncine katkıda bulunur [9]. Magnezyum insülin etkinliğinde önemli bir role sahiptir ve insülin, insüline duyarlı dokularda magnezyum alımını teşvik eder. Tip 2 diyabeti olan hastalarda plazma magnezyum ve insülin direnci arasında ters bir ilişki olması nedeniyle hücre içinde değişiklikler olmakta, insülin duyarlılığı değişebilmektedir. Hücre içi magnezyum eksikliği insülin direnci gelişimini etkileyebilir ve hücre içine glikoz girişini değiştirebilir $[9,11,12]$. Çalışmamızda hipomagnezemi grubunda ortalama glukoz ve HbA1c düzeyleri anlamlı bir şekilde daha yüksek saptandı.

Tip 2 DM ile serum magnezyum düzeyi arasında bir ilișki olduğuna ilişkin çeşitli kanıtlar ileri sürülmektedir [13, 14]. Dasgupta ve ark.'nın yapmış oldukları çalışmada 150 Tip 2 DM hastasının \%11,33'ünde magnezyumun düşük düzeyli olduğu rapor edilmiştir [15]. Baig ve ark. komplikasyonu olmayan Tip 2 DM sahip ve yaşları (4070) arasında olan hastalarda yaptıkları çalışma sonucunda magnezyum düzeyini anlamlı olarak düşük bulduklarını rapor etmişlerdir. [16]. Benzer şekilde Lind ve ark.'nın orta yaşlı bozulmuş glikoz toleransına sahip 52 erkek DM hastalarında yaptıkları çalışma sonucunda serum magnezyum düzeyinin düşük olduğunu rapor etmişlerdir [17]. Çalışmamızda, 189 Tip 2 DM hastası çalışmaya dahil edildi ve bu hastaların \%34'ünde hipomagnezemi saptandı

Diyabet ve proteinüri hipomagnezemi için önemli risk faktörleri olarak ileri sürülmüştür. Tip 2 DM hastalarında düşük magnezyum düzeyi ile HbA1c düzeyleri arasında ilişki olduğu literatürde bildirilmiştir. Ancak, bazı çalışmalarda Tip 2 DM hastalarının magnezyum düzeyi ile HbAlc arasında bir ilişki saptanamamıştır [18]. Çalışmamızda ise Tip $2 \mathrm{DM}$ hastalarında düşük magnezyum düzeyine sahip hastalarda ortalama HbAlc düzeylerini anlamlı bir şekilde yüksek bulduk. Bunun yanında serum magnezyum düzeyi ile $\mathrm{HbAlc}$ değerleri arasında zayıf da olsa negatif bir korelasyon saptandı. Çalışmamızda, düşük magnezyum düzeyine sahip hastalarda ortalama proteinüri miktarının daha yüksek gözlendi ve serum magnezyum düzeyi ile proteinüri değerleri arasında zayıf da olsa negatif bir korelasyon saptand. Proteinüri ile hipomagnezemi ilişkisi massif proteinürisi olan hastalarda tubüler disfonksiyona bağlı renal magnezyum kaybının artışı ile açıklanmaya çalışılmıştır. Vitamin D eksikliği de barsaklardan magnezyum emilimini azaltarak düşük serum magnezyum düzeyine katk1 da bulunuyor olabilir [19]. Ancak diyabetik hastalarda hipomagnezemi sadece proteinüri ile açıklanamamıştır. Diyabetik hastalarda intestinal magnezyum emilimi de bozulmuş olabilir.

Tip 2 DM hastalarında hipomagnezeminin glomerüler filtrasyon hızını etkilediği bilinmektedir. Hipomagnezemi, Tip 2 DM ve diyabetin kronik komplikasyonlarının gelişimi ile de ilişkili olabilir. Tip 2 DM hastalarında hipomagnezemi ile böbrek fonksiyonu arasında ilişki olduğu ve magnezyum düzeyi düşük olan hastalarda böbrek fonksiyonlarının daha hızlı bozulduğu da ileri sürülmüştür. Pham ve ark. 550 DM hastada yapmış oldukları çalışma sonucunda serum magnezyum düzeyi ile GFH arasında negatif yönlü anlamlı bir ilişki olduğunu rapor etmişlerdir [20]. Bizim çalışmamızda ise Tip 2 DM hastalarında serum magnezyum düzeyi ile eGFR arasında anlamlı bir ilişki gözlenmedi.

Yapılan bir başka çalışmada diyabetik hastalarda ileri yaş, zayıf glisemik kontrol ve düşük eGFR'nin, düşük serum magnezyum düzeyinin en önemli belirleyicisi olduğu bildirilmiştir [21]. Çalışmamızda serum magnezyum düzeyi ile yaş, beden kitle indeksi, eGFR, diyastolik ve sistolik kan basıncı arasında anlamlı bir ilişki saptanmadı.

\section{Sonuç}

Sonuç olarak, hipomagnezemi Tip 2 DM hastalarında sık görülmektedir. Tip 2 DM'si olan hastalarda serum magnezyum düzeyi ile glisemi regülasyonu ve proteinüri arasında zayıf da olsa anlamlı bir ilişki olabilir. Glisemi regülasyonu bozuk olan diyabetik hastalarda serum magnezyum düzeyinin kontrol edilmesi önemlidir.

\section{Referanslar}

1. Guariguata, L, Whiting, D.R, Hambleton I, Beagley J, Linnenkamp, U, Shaw, J.E, Global estimates of diabetes prevalence for 2013 and projections for 2035, Diabetes Research and Clinical Practice, 2014,103 (2), 137-49

2. Agrawal P, Arora, S , Singh, B, Manamalli, A, Dolia, PB, Association of macrovascular complications of type 2 diabetes mellitus with serum magnesium Levels, Diabetes \& Metabolic Syndrome. Clinical Research \& Reviews, 2011, 5, 41-44.

3.Zhang, J, Wang, H, Wang, Z, Zhang, J, Zhang, B, Association between Toenail Magnesium and Type 2 Diabetes in Chinese Adults, Nutrients, 2017, 9 (8)

4.Jahnen-Dechent, W, Ketteler, M, Magnesium basics, Clinical Kidney Journal, 2012, 5 (Suppl 1), i3-i14.

5.Pasternak K, K.J, Horecka A, Biochemistry of magnesium, Journal of Elementology, 2010, 15, 601-616.

6. Swaminathan, R, Magnesium metabolism and its disorders, The Clinical Biochemist Reviews, 2003, 24 (2), 47-66.

7. Kurtuluş, İnci, D.S, Uçkan, Ü, Gestasyonel diyabetes mellitusta serum magnezyum düzeyleri. Türk Aile Hek Derg, 2010, 14 (2), 64 70 .

8. Sobczak, A.I, Stefanowicz, F, Pitt, SJ, Ajjan, RA, Stewart,AJ, Total plasma magnesium, zinc, copper and selenium concentrations in type-I and type-II diabetes. Biometals, 2019, 32 (1), 123-138.

9. Takaya, J, Higashino, H, Kobayashi, Y, Intracellular magnesium and insulin resistance, Magnesium Reserach, 2004, 17 (2),126-36.

10. Elin, R.J, Magnesium: the fifth but forgotten electrolyte, American Journal of Clinical Pathology, 1994, 102 (5), 616-22.

11. Karamali, M, Bahramimoghadam, S, Sharifzadeh, F, Asemi Z, Magnesium-zinc-calcium-vitamin D co-supplementation improves glycemic control and markers of cardiometabolic risk in gestational diabetes: a randomized, double-blind, placebo-controlled trial Applied Physiology, Nutrition, and Metabolism, 2018, 43 (6), 565570.

2. ELDerawi, W.A, Naser, I.A, Taleb, M.H, Abutair, A.S, The effects of oral magnesium supplementation on glycemic response among type 2 diabetes patients. Nutrients, 2019, 11 (1), 44. 
13. Niranjan, Y, Anitha, D, Srinivasan, AR, Kuzhandai Velu, V, Venkatesh, C, Sathish Babu, M, Ramesh, R, Saha, S, Association of inflammatory sialoproteins, lipid peroxides and serum magnesium levels with cardiometabolic risk factors in obese children of South Indian population, International Journal of Biomedical Science, 2014, 10 (2), 118-23.

14. Kocot DL, S.M., Wiśniewska MN, Dąbrowski A, Andrzejewski A ,Wallner G, Pasternak K, Sztanke K, Plasma magnesium and calcium concentrations and selected biochemical parameters in patients with type 2 diabetes mellitus, Current Issues in Pharmacy and Medical Sciences, 2012, 25 (2), 126-31.

15. Dasgupta, A., D, Sarma, and U.K. Saikia, Hypomagnesemia in type 2 diabetes mellitus, Indian Journal of Endocrinology and Metabolism, 2012, 16 (6), 1000-3.

16. Baig MS, Shamshuddin M, Mahadevappa KL, Attar AH, Shaikh AK, Serum magnesium as a marker of diabetic complications, Journal of Evoluation of Medical and Dental Sciences, 2012, 1 (3), 119-23.

17. Lind, L, Lithell H, Hvarfner A, Ljunghall S, Indices of mineral metabolism in subjects with an impaired glucose tolerance, Experimantal Clinical Endocrinology, 1990, 96 (1), 109-12.

18. Srinivasan, A.R, Niranjan, G, Velu V.K, Parmar P, Anish,A,Status of serum magnesium in type 2 diabetes mellitus with particular reference to serum triacylglycerol levels, Diabetes \& Metabolic Syndrome: Clinical Research \& Reviews, 2012, 6 (4), 187-189.

19. Oka, T, Hamano, T, Sakaguchi, Y, Yamaguchi, S, Kubota, K, Senda, M, Yonemoto, S, Shimada,K, Matsumoto,A, Hashimoto, N, Mori1,D, Monden,C, Takahashi, A, Obi,Y, Yamamoto, R, Takabatake,Y, Kaimori, J, Moriyama, T, Horio, M, Matsui,I, Isaka $\mathrm{Y}$, Proteinuria-associated renal magnesium wasting leads to hypomagnesemia: a common electrolyte abnormality in chronic kidney disease, Nephrologhy Dialysis Transplantation, 2019, 34 (7), 1154-1162.

20. Pham, PC., PM. Pham, and PT. Pham, Patients with diabetes mellitus type 2 and hypomagnesemia may have enhanced glomerular filtration via hypocalcemia, Clinical Nephrology, 2012, 78 (6), 442-8.

21. Pokharel, D.R, Khadka, D, Sigdel M, Yadav N.K, Kafle R, Sapkota, R.M, Jha, S.K, Association of serum magnesium level with poor glycemic control and renal functions in Nepalese patients with type 2 diabetes mellitus, Diabetes \& Metabolic Syndrome: Clinical Research \& Reviews, 2017, 11, 417-423.

http://edergi.cbu.edu.tr/ojs/index.php/cbusbed isimli yazarın CBU-SBED başlıklı eseri bu Creative Commons Alınt1-Gayriticari4.0 Uluslararası Lisansı ile lisanslanmıştır.

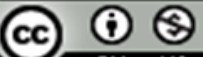

